\title{
The Gulag of Poets: The Experience of Exile, Forced Labour Camps, and Wandering in the USSR in the Works of Polish- YIDDISH WRITERS (1939-1949) ${ }^{1}$
}

\author{
Magdalena Ruta \\ (iD) https://orcid.org/0000-0003-0556-1694 \\ (Jagiellonian University in Krakow, Poland) \\ e-mail: dlamagdaleny@gmail.com
}

Keywords: the Holocaust, WWII, the Soviet Union, Polish Jews, Yiddish literature, Communism, exile, Soviet Forced Labour Camps, wandering in the USSR

Abstract: The literary output of the Polish-Yiddish writers who survived WWII in the Soviet Union is mostly a literary mirror of the times of exile and wartime wandering. The two major themes that reverberate through these writings are: the refugees' reflection on their stay in the USSR, and the Holocaust of Polish Jews. After the war, some of them described that period in their memoirs and autobiographical fiction, however, due to censorship, such accounts could only be published abroad, following the authors' emigration from Poland. These writings significantly complement the texts produced during the war, offering plentiful details about life in Poland's Eastern Borderlands under Soviet rule as it was perceived by the refugees, or about the fate of specific persons in the subsequent wartime years. This literature, written in - and about - exile is not only an account of what was happening to Polish-Jewish refugees in the USSR, but also a testimony to their coping with an enormous psychological burden caused by the awareness (or the lack thereof) of the fate of Jews under Nazi German occupation. What emerges from all the literary texts published in post-war Poland, even despite the cuts and omissions caused by (self)censorship, is an image of a postwar Jewish community affected by deep trauma, hurt and - so it seems - split into two groups: survivors in the East (vicarious witnesses), and survivors in Nazi-occupied Poland (direct victim witnesses). The article discusses on samples the necessity of extending and broadening of that image by adding to the reflection on Holocaust literature (which has been underway for many years) the reflection on the accounts of the experience of exile, Soviet forced labour camps, and wandering in the USSR contained in the entire corpus of literary works and memoirs written by Polish-Yiddish writers.

After Germany's invasion of Poland, a relatively large group of Polish-Yiddish writers found themselves living on the country's eastern frontiers that had been annexed by the Red Army on 17 September 1939. The exact number of these refugees remains unknown, especially if we take into account that many of them lost their lives in dramatic

${ }^{1}$ This paper has also been published in Polish under the title Gutag poetów. Doświadczenie uchodźctwa, tagrów i tułaczki na terenie ZSRR w twórczości polskich pisarzy języka jidysz (1939-1949), in: L. Zessin-Jurek and K. Friedla (eds.), Syberiada Żydów polskich. Ucieczka przed Holokaustem, Warszawa 2020: 307-337. 
circumstances following Germany's attack on the USSR. ${ }^{2}$ Neither do we know the number of Jewish writers who, having fled from Poland, died in the interior of the Soviet Union later in the war. What we do know is the approximate number of those writers who managed to survive and return to their Polish homeland during the so-called first repatriation. Immediately after the war, about a hundred of them came back to Poland, ${ }^{3}$ but the majority only stayed there for a short while and soon left for Israel, the United States, or Argentina via France. Only a small group - those who supported the political transformation taking place in Poland at that time - decided to permanently resettle in their homeland.

The reconstruction of Jewish cultural life in Poland had started even before the warfare was officially over. Dos Naye Lebn, the first Yiddish newspaper established after the war, welcomed submissions from writers as early as April 1945. Also in that year, the first volume of poetry after the Holocaust - Di shtilkayt mont by Mendel Man ${ }^{5}$ - was published. In the first few years after Poland's liberation (1945-1948/1949), a period of relative political freedom, Jewish publishing houses such as Nidershlezye, Dos Naye Lebn, and Yidish Bukh, ${ }^{6}$ released mostly literary works written during the war. A small fraction of these books were texts produced in the ghettoes of Nazi-occupied Poland, while the vast majority had been written in the Soviet Union. ${ }^{7}$ Dominated by poetry, ${ }^{8}$ the literary output of the writers referred to as the "survivors in the East" is mostly a literary mirror of the times of exile and wartime wandering. Two major themes reverberate through these writings: the refugees' reflection on their stay in the USSR, and the Holocaust of Polish Jews. ${ }^{10}$

\section{$* * *$}

For the refugees from Poland, their sojourn in the Soviet Union was split into two phases. The first lasted from the annexation of Poland's Eastern borderlands until the outbreak of the German-Soviet war, and for various reasons, proved to be a positive experience for many of them, at least at the very beginning. It can be concluded from the memoirs and literary works that Jews fled eastwards full of hope, and that after their arrival in the area which was controlled by Soviet power they regained not only a sense

2 Over 260 Yiddish writers and journalists from Poland died in the Holocaust, which almost amounts to the number of writers registered in the Association of Jewish Writers and Journalists in 1929.

3 See Żółkiewska 2017: 71.

${ }^{4}$ See Nalewajko-Kulikov 2007: 257-278.

5 Man 1945.

${ }^{6}$ See Nalewajko-Kulikov 2008: 129-164.

7 See the list of literary works published in 1945-1949 in: Ruta 2008: 248-250.

8 As Gennady Estraikh notes, already in the Białystok period, i.e. during the first few months after the annexation of Poland's Eastern borderlands by the USSR, poets were the first to provide accounts of the new reality. See Estraikh 2016: 184. Undoubtedly, the modest length of lyrical texts enables poets to react instantly to stimuli they consider significant, whereas prose writing, it appears, demands a longer temporal distance. It remains a fact that in the entire bulk of all literature produced by refugee writers (published in post-war Poland, as well as abroad, following the authors' emigration) poetry predominates.

9 The term was inspired by the title of an extensive interview with Julian Stryjkowski Ocalony na Wschodzie. Z Julianem Stryjkowskim rozmawia Piotr Szewc 1991.

${ }^{10}$ For a detailed analysis of some of the topics mentioned in this paper see Ruta 2017. For Polish translations of some of the poems and short stories discussed in this paper see Ruta 2012 and Ruta 2018. 
of security, but also their personal dignity: "The terror of those days is over, / the nights filled with fear have come to an end; / never again the disgraceful patch - / for I am a slave no more... // [...] I am on this side now / and I can breathe freely"11 - the Sionist poet Avrom Zak wrote on 12 December 1939 in his poem "Af yener zayt Bug" [On the other side of the Bug River], having crossed German-Soviet border at Siemiatycze. The Jewish intelligentsia sought shelter mostly in the two borderland cities of Lwów/Lwiw and Białystok. ${ }^{12}$ Those writers who were associated with Communism and enjoyed the privilege of being trusted by the new authorities immediately started to cooperate with the Communist Yiddish press, such as Bialistoker Shtern - a new paper established in Białystok at that time; they were also presented with the opportunity to publish their books of verse, ${ }^{13}$ and many of them were welcomed as members of professional organizations for Soviet writers - the Belorussian Writers' Union, and the Ukrainian Writers' Union. In both of these cities Communist writers also held top positions in cultural institutions and governing bodies. ${ }^{14}$

After the war, some of the "survivors in the East" described that period in their memoirs and autobiographical fiction, although due to censorship such accounts could only be published abroad, following the authors' emigration from Poland. ${ }^{15}$ These writings significantly complement the texts produced during the war, offering plentiful details about life in Poland's Eastern borderlands under Soviet rule as it was perceived by the refugees (zapadniki, i.e. "westerners"), or about the fate of specific persons in the

11 Zak, "Af yener zayt Bug," in: idem 1949: 31. All quotations from Yiddish literature have been translated into Polish by the author of this paper, and from Polish into English by Maria Piechaczek-Borkowska.

12 There were about forty Yiddish writers living in each of these two cities. For more on the subject of the presence of Jewish writers from Poland in Lwów and Białystok see Levin 1995: 126-143; Szymaniak 2006: 55-60; Estraikh 2016: 176-191; Molisak 2020.

${ }^{13}$ In 1940-1941 books of verse of such writers as Isroel Ashendorf, Binem Heller, Moyshe Knaphays, Isroel Emiot, Josef Rubinshteyn, Sholem Zhirman, Aron Val, Nokhem Bomze, Yerakhmiel Grin, Mikhoel Burshtin, and Rokhl Korn were published in the USSR. For more see Levin 1995: 134 and Estraikh 2016: $185-186$.

14 See Levin 1995: 126-143; Estraikh 2016: 176-191; and Nalewajko-Kulikov 2009: 114.

15 The period from the late 1940s and early 1950s through the 1960s saw a peak in memoir writing among the "survivors in the East" who had emigrated from Communist Poland. As Laura Jockusch and Tamar Lewinsky have noted, it was not until they had started to write and publish beyond the zone of Communist influence that the authors of these memoirs were able to reveal their highly critical attitude towards the Soviet state. See Jockusch and Lewinsky 2010: 373-399. Estraikh, on the other hand, points out that while documenting their encounters with Soviet Yiddish writers in their memoirs, Yiddish writers from Poland tend to justify their cooperation with the Communist regime by regarding them as contemporary Marranos, living a double life and remaining faithful to their Jewishness in secret despite the unfavourable circumstances. According to that scholar, refugees from Poland would find this theory helpful in justifying their own collaboration with the Soviet authorities: "They could argue that, unlike the original Soviet Yiddish writers [...] the Polish-Yiddish writers never 'changed their skin.' Instead, they portrayed their Soviet years as a story of forced and painful compromises." See Estraikh 2016: 188. Furthermore, the scholar observes that the abundance of autobiographical literature produced by Polish writers creates an expressive background for the surprising lack of memoirs by Soviet writers (this was said in a private conversation with the author of the present paper). While verse and prose written and published by Yiddish writers in the Polish People's Republic have already been critically described to a certain extent (see Ruta 2017), their memoirs and fiction focusing on the Soviet period are still awaiting critical analysis. This relatively large collection of memoirs, written in a hermetic language by Jews who were not assimilated to Polishness and revealed a strong national identification may prove to be an interesting source of information, e.g. on Polish-Jewish relations in those tragic times. 
subsequent wartime years. Thus, we are presented with images of the Polish borderland cities of Białystok, Grodno, and Lwów, packed with refugees arriving in increasingly great numbers across the border along the Bug and San Rivers. The new authorities were quite unprepared to receive such an influx, ${ }^{16}$ hence the newcomers' problems in finding lodging, jobs, and food. Other aspects of the new reality discussed in the memoirs include the rapid impoverishment of society, shops being emptied, the atrophy of cultural and social life, the replacement of the old social elites by the new authorities, and the social advancement of those individuals who proved mediocre but loyal to the new administration. ${ }^{17}$ The once picturesque towns appeared dull to the refugees, and the eyes of the local residents looked sad and mistrustful. ${ }^{18}$ The newcomers noticed that the new authorities would ruthlessly crush anyone they considered to be their enemy. Arrests and transport of Polish citizens to unknown destinations began relatively early, which created an omnipresent atmosphere of fear, as reflected in the writers' recollections. Kalman Segal notes in his short story "Relsn" [The tracks]:

It's midnight already, but the whirr of military vehicles can still be heard, and the wheels of peasant carts roll, bouncing, on the paved roads. In each vehicle, there's a man in uniform. One of them will soon stop by your door. Someone will knock. Softly at first, and then impatiently, violently. Are you ready? You'd better shut the window if you live on a high story, or your black despair might push you to a desperate act. ${ }^{19}$

In that period a number of writers such as Avrom Zak, Moyshe Grosman, Leyb Olitski, Kalman Segal, Dovid Zakalik, and Yankev Kahan, journalists like Betsalel Terkel, Ovadye Feld, and Leo Finkelshteyn, and actors including Shimen Dzhigan, Yisroel Shumakher, Dovid Lederman, and Nusin Vulfovitsh, were sentenced to prison or banished to Soviet forced labour camps.

The literature that appeared in print in Communist Poland directly after the war primarily shows the positive aspects of Soviet life in 1939-1941, paying particular attention not only to the sense of security and freedom, but also to the equality of all people before the law. New paths opened for Jews - opportunities which they had not had in the Second Polish Republic (1918-1945). And so, for example, the protagonists of Kalman Segal's ${ }^{20}$ and Yitskhok Guterman's ${ }^{21}$ short stories complete their school education and go on to universities. Obviously, the tone in this kind of texts was not devoid of propaganda, as in a short story titled "Opowiadanie z zabitego Miasteczka" [The tale of the murdered shtetl] in which Segal describes the changes that took place during the Soviet era in the social, economic, and - probably most importantly - the psychological, spheres:

Peasants started to place more confidence in life and in the future now. Never before had they laughed so earnestly and with such joy. Long trains loaded with tractors arrived from Kiev.

16 On this subject see e.g. Boćkowski 2006: 85-123.

17 See e.g. Dzhigan 1974: 156-164.

18 See the memoirists' comments on the changes taking place in the urban landscape, as well as in the appearance, customs, and language of the city dwellers: Dzhigan 1974: 150-165, Zak 1956: 7-39, 59-68, or Grim (Grosmann) 1949: 20-106.

19 Segal 1981: 87.

20 See Segal 1960: 95-125 (Yiddish version) and Segal 2017: 105-158 (Polish version).

21 Guterman Y. 1949: 41-57. 
The lord's estate was being distributed, old baulks were being ploughed up - new life was barging in on Ukrainian Subcarpathia.

I watched these changes taking place, rejoiced over other people's joy. Young people like me worked for the Komsomol, entered universities.

New schools were being opened, the young and the old had fun in clubhouses.

I trod firmly down the streets of the town, and I didn't worry about tomorrow, about finding a job, about bread, or a place to live. I knew that now I would not perish anymore. ${ }^{22}$

Binem Heller dedicates an exceptional amount of attention to the new reality, and even writes of "an era of freedom" that started in the Polish Eastern borderlands with the arrival of the Red Army:

No more the hangman's rope

That choked my song.

My voice will not be throttled,

The high heavens protect me.

The wide world is before me,

Awaiting the sound of my words.

The Red Army has liberated

And given into my custody this land..$^{23}$

This (ostensible) idyll on the Soviet side was for the refugees disturbed by their fear for the fate of their relatives and friends under Nazi German occupation. However, Polish Jews could not express these fears openly, because from the autumn of 1939 until the early summer of 1941 all criticism of Germany (USSR's ally at that time) was prohibited. This is how Zak remembers his attempt to publish a poem containing allusions to the fate of Jews in Nazi-occupied Poland in the Communist newspaper Bialistoker Shtern:

I'm sitting in the small editorial office with "comrade editor" who is reading the two poems

I have submitted. I can tell that he's embarrassed, and his anxiety concerns several excerpts [...]. While reading them, he instinctively falls silent and ponders for a while [...]. It is obvious that they make him uncomfortable... [...] The editor halts mostly at the line which says that Germans are forcing Jews to "dig their own graves"... Now, that's, obviously, a clear allusion, and an attack on Soviet Union's "ally"...

"Well, what do you say, comrade editor? I do believe that on this side poems like these should be published..."

"Leave them here... We'll see..."

[...] Several days passed, and then, of course, it transpired that the poems were not being published. ${ }^{24}$

An echo of the anxiety about one's family and friends can be heard in the rare poems composed during the first two years of the war, most of them written by Heller, the greatest enthusiast of Soviet rule. ${ }^{25}$ However, even this author never openly says who the tormentor of Polish Jews is. Moreover, in his works the word "Germans" never appears

22 Segal 2017: 136.

${ }^{23}$ Heller, "Bafrayt" [Liberated], in: idem 1948: 52-53.

${ }^{24}$ Zak 1956: 30-31.

${ }^{25}$ Among the poems printed in post-war Poland, only a few, written in the above-mentioned period, reveal traces of care about one's near and dear ones who had been left behind, and who are either dead already, 
in a negative context, such as in his poem "Ikh bin do" [I am here], written in the autumn of 1939 in Białystok. This is how he describes the situation of his persecuted compatriots in that poem:

A crow flies from there [from Warsaw] squawking:

The leaves of yellow patches are falling!

Small Jews bent double

Are taking them with them.

Small Jews - in place of eyes

Deep holes full of fear. - - - 26

In his poems "Mayn mame in geto" [My mother in the ghetto] from 1940, and "Opklang fun duner" [The echo of a thunderclap] from 1941 the poet clearly - although without forming specific accusations - talks about the sharp contrast between the safe life on the Soviet side of the Bug River, and the life filled with humiliation, violence, hunger and disease in the Warsaw Ghetto. ${ }^{27}$ In this series of poems, we encounter traces of ambivalence resulting, most probably, from the discord between Heller's confidence in Stalin (who had entered into an alliance with the Germans), and his internal protest against Germany's policy on Jews. Despite his anxiety, Heller still attempts to justify the current state of affairs: "I know it is hard to bite one's lip, / when I hear crying / from the other side of the border, / but now we must guard the Bug River." ${ }^{28}$ It seems that some of the works written by that brilliant poet during the early years of the war testify to his internal conflict between what he felt should be written about the fate of Polish Jews, and his careful observance of the boundaries of what was officially permissible. A year before the outbreak of the German-Soviet war, Heller would write almost literally about this double logic: "I can hide my hatred, / but it is still legitimate. / And even if I were to wait until tomorrow to be paid, / I shall demand payment for yesterday as well... ${ }^{29}$ So, the lyrical speaker of the poem "Mayn mame in geto" promises that although he has to keep quiet now, in the future he shall avenge the suffering of his mother, who is "walled in the Warsaw Ghetto" ${ }^{30}$ and here symbolizes the entire nation.

$$
* * *
$$

For the refugee writers, the second phase of their life in the USSR began with the sudden outbreak of the German-Soviet war. From that moment on, the theme of the Holocaust would occupy more and more space every year. Literary works from that period printed in post-war Poland still basically revolve around the subjects I have already mentioned here: anxiety for the fate of Jews under Nazi German occupation, and reflection on the hardships of the wartime wandering in the USSR. Poverty, homelessness, hunger,

or whose lives are in danger. See Guterman G., "A briv tsu tatn" [A letter to father], in: eadem 1948: 5-7, and Ivan, "A briv fun mayn mamen" [A letter from my mother], in: idem 1950: 21-22.

26 Heller, "Ikh bin do," in: idem 1948: 42.

27 Heller, "Mayn mame in geto," in: idem 1948: 86-87; Heller, “Opklang fun duner," in: Ibid.: 88-89.

28 Heller, "Bam Bug" [By the Bug], in: idem 1948: 63.

29 Ibid.

${ }^{30}$ Heller, "Majn mame in geto," in: idem 1948: 86-87. 
disease, fear, humiliation, and homesickness - these are the problems that the majority of refugees had to tackle in that time and place, regardless of their nationality and political views. As I have already mentioned, the "survivors in the East" would not write, or to be more precise, would not publish anything on political repression in the USSR until their emigration from Poland. Interesting material for comparative analysis in this area is offered by the publications of those authors who had been prisoners in Soviet prisons or forced labour camps. For example, in the book of poetry by Avrom Zak Mit ash afn $k o p$ [With ash on one's head], published in Warsaw in 1947, out of the total number of 54 narrative poems, 44 are marked as written in the USSR. Most of them are dedicated to murdered Polish Jews, and only a few contain reflections on the wanderer's fate, or the beauty of the Orient. In this collection, Zak does not even mention his sojourn in a Soviet forced labour camp. However, as soon as in the next volume, titled Yorn in vandern [Years of wandering], published in Paris in 1949 (two years after his departure from Poland), the poet devotes some of the poems to issues like arrest, deportation, and life in a Soviet forced labour camp. In a poem titled "Durkh a kratn fentsterl" [Through a barred window], written in 1940 during a journey on an army train, taking Zak to a camp in the Republic of Komi, ${ }^{31}$ the poet says goodbye to his relatives. In that seemingly innocent farewell, the only sign of the strong feeling of tension that accompanies the lyrical speaker is the short exclamation: "The wheels whirr monotonously. Always the same, through night and day. / Fate is leading me to distant, foreign lands... / Oh God! My hair has suddenly turned white! / I have turned grey prematurely, long before my time - - .." ${ }^{32}$

Speaking indirectly about the politically conditioned experiences of the Soviet odyssey is a typical feature of Zak's refugee poetry written in "the motherland of the proletariat." ${ }^{33}$ The writer ventures to write with more openness only in those poems which present the war-torn world in a more general sense, without addressing the wartime Soviet reality. For instance, in a poem titled "Evakopunkt" [Evacuation point] written in Tashkent in 1941, Zak portrays the harsh conditions in one of the evacuation points where, at the turn of 1941 and 1942, Polish citizens intending to join Anders' Army (the Polish Armed Forces in the East) were gathered, having been released from prisons and Soviet forced labour camps following the signing of an agreement between the governments of Poland and the USSR in the summer of $1941 .{ }^{34}$ Zak notes: "Army trains keep

${ }^{31}$ Komi Autonomous Soviet Socialist Republic was an important point on the map of Soviet Gulag.

32 Zak, "Durkh a kratn-fentsterl," in: idem 1949: 35.

33 Cautiousness, or circumspection of statements concerning politically sensitive subjects is an immanent trait of Zak's refugee poetry. The writer himself confirms it in the second volume of his memoirs Af shliakhn fun hefker, when he describes the preparations for repatriation in 1946. Among the works written in the USSR, mostly devoted to the Holocaust, there were some "non-kosher" poems as well - verse written in a Soviet forced labour camp. "I had to camouflage these poems with forgeries. I titled the whole [Soviet labour camp] series 'In a German Concentration Camp'... I also changed some words in the text that sounded too self-evident. Once I'm on the other side, I'll obviously correct everything." See Zak 1958, vol. 2: 371. This remark helps us to understand the existence of double dates and places of composition given under many of Zak's poems, where the first date and place usually refer to the wartime period in the USSR, while the second date and place refer to the post-war period in Poland.

34 On 30 July 1941 the governments of Poland and the USSR, represented by Polish Prime Minister, Gen. Władyslaw Sikorski and Soviet Ambassador to the United Kingdom, Ivan Mayski, signed a treaty, pursuant to which an amnesty was granted to all Polish citizens imprisoned in the USSR at that time. See e.g. Wyrwa 1992: 198-203. 
coming, / spitting out crowds of people here. / Their dirty mass keeps growing, / hungry, naked, and barefoot." 35 A similarly tragic image emerges from the poem "Guzar," where the poet gives an account of the situation in which Polish refugees, gathered in an organization centre of Anders' Army, found themselves in 1942. The newcomers were quartered in a tent village:

But uninvited guests come to the tents as well scurvy and typhoid fever... Still taking their toll.

Every morning behind the tents, at the edge of the hill, the row of dead bodies grows longer.

"Mountain of Death"... A cruel mockery of mischievous demons!

But it does not terrify the wanderers...

From all directions - from Orenburg, Tashkent, and Jalal-Abad -

New crowds of the homeless keep flooding in...

Oh, the town of Guzar! You

gave us forty dead daily,

and down in the valley nearby

our own cemetery grew. ${ }^{36}$

As a side note, it seems legitimate to add that not being admitted into the then-forming units of Anders' Army was a slap in the face for many Polish Jews. This kind of rejection was experienced not only by Zak, but also, for instance, by Moyshe Shklar. And yet, interestingly, this episode was never mentioned in their poetic output. Moreover, in all the literary legacy of Polish-Yiddish writers I am familiar with, so far I have not come across a single poetic text addressing this issue. However, it remains the subject of bitter reflection in the memoirs and accounts of many Jewish refugees, including those of the Yiddish intelligentsia. ${ }^{37}$

${ }^{35}$ Zak, "Evakopunkt," in: idem 1949: 44-45. Place and time of the poem's composition: Tashkent 1941Łódź 1947.

${ }^{36}$ Zak, "Guzar," in: idem 1949: 48-49. Place and time of the poem's composition: Guzar 1942 - Łódź 1947. Guzar (G'uzor) is a town in Uzbekistan which boasted an organizational centre of Anders' Army, a field hospital, and the main typhoid fever quarantine camp, as well as a war cemetery - the largest war necropolis in that republic, the last resting place of 700 Polish citizens. According to Daniel Boćkowski, the causes of the high mortality rate among Polish people gathering in the towns of USSR's southern republics were malnutrition, a climate that favoured the spread of infectious and gastrointestinal diseases, as well as lack of cleansing agents and a scarcity of water. The situation was most critical in Uzbekistan. See Boćkowski 1999: 234.

${ }^{37}$ This is how this outrageous question is described by Yitskhok Edison, the author of incredibly interesting memoirs titled Mayne fir yor in Soviet-Rusland [My four years in Soviet Russia], who applied to join the Polish Army in Buzuluk: "Already on the first day [of the medical evaluation board's work] the rumours spread that Jewish candidates for soldiers were being insulted by the board. [...] A few days passed, and the rumours proved true. When it was finally my turn to face the medical board, I was preparing myself for 'special' treatment, but then my spirits rose when I was ordered to enter the examination room together with a group of Poles. Almost all of them looked emaciated and haggard, and their bodies were covered with swelling and wounds - the reminders of Soviet forced labour camps. Compared to them, I looked like a hero. [...] However, the verdict of the military board was different than I had expected. All the Poles without exception were admitted into the army, whereas for me the board found some kind of 'catch,' declaring me to be temporarily unfit for military service. The board's decision infuriated me, so I asked the chairman, a Polish major, why I had been rejected, while people older than me and severely ill had been accepted. He answered 
The aforementioned Avrom Zak is the author of an extensive four-volume memoir published in two parts: Knekht zenen mir geven [We were the slaves], and Oyf shliakhn fun hefker [On the roads of anarchy], dedicated in their entirety to his Soviet experiences of 1939-1946. ${ }^{38}$ His poetry and memoirs are complementary, combining facts with the sphere of public feeling, the writer's emotions, historiosophic commentary, and poetic reflection. Here are two examples:

In the second volume of his memoirs Knekht zenen mir geven, which presents an account of his stay at the Soviet forced labour camp Ukhtizhemlag in Komi Republic, Zak describes the Jewish Yom Kippur ${ }^{39}$ holiday in 1940, which he spent in confinement, far from family and friends. As part of his duties, he had to cooperate with a Soviet cartographer to document the course of the Tshibiu River near Ukhta. The writer mentions not only the harsh living conditions, but also the difficult emotions he experienced during that most important of all Jewish holidays:

I am sitting on the bank of the River Tshibiu, over the churning water. Suddenly, I remember that today is the eve of Yom Kippur. The sun will soon be setting. The time for the Kol Nidre prayer will come:

In the rumble of the river I can hear myself, and it seems to me that I can discern the sounds of prayer... That there are people somewhere around, praying... That the sounds of prayers are coming from some nearby synagogue, filled to the brim...

[...]

- Kol Nidre - - -

Along with the tones of the prayer rise - my sobs - - - I am a man, but I cannot remember if I have ever cried as much as I did by the River Tshibiu... ${ }^{40}$

Echoes of that experience can be found in several of Zak's narrative poems, such as in "Kol Nidrey ba Tshibiu" [Kol Nidre by the River Tshibiu]. At that particular time, the space of the taiga undergoes a peculiar transformation, becoming one great temple filled with prayers offered up to God: "Kol Nidre - - - The wood is not just a wood any more - / it is a crowd immersed in prayer, a crowd silently whispering... / The glow of sunset like the light of the synagogue, / and in the green space, there rests the Shekhinah - - -." ${ }^{41}$ In a poem titled "Tshibiu," on the other hand, Zak ventures to voice a quiet complaint,

me with blatant, overweening arrogance that it was a Polish army, and not a Jewish one. My hands were shaking with irritation, so, having nothing to lose, I told him what I thought of him. I did not spare his person, or his uniform. And then, a scandal broke." See Edison 1953: 150-151.

38 See: Zak 1956 and Zak 1958.

39 Yom Kippur - a day of atonement and fasting which completes the period of ten days of repentance, considered to be the most solemn day of the year in the Jewish liturgical calendar. According to Jewish tradition, it is on that day that every man's fate is decided. See the entry "Yom Kippur," in: https://www.britannica. com/topic/Yom-Kippur (Accessed: 27 January 2020).

40 Zak 1956, vol. 1: 88-89.

41 Zak, "Kol Nidrey ba Tshibiu," in: idem 1949: 37. Place and time of the poem's composition: Ukhta (Komi), 1940 - Ural, 1942. 
emphasising the unity of his individual fate with the fate of the entire Jewish nation: "Tshibiu, Tshibiu! / [...] For hours I sit by your / dark waters, / and listening to their quiet murmur, / I hear a sob / / the voice of generations, / the weeping of generations, / 'on the banks of Babylon' - - -." 42 These words reveal the deeply felt communion of fate with distant generations (see Psalm 137) with whom the Soviet forced-labour camp prisoner shares his sadness and mourning over the loss of motherland and personal freedom.

Another experience that awoke strong emotions in the writer which he sought to express in the poetic form was the end of the war in itself. And so, the poem "Gebentsht zoln zayn..." [Let them be praised...] from April 1945, published in the "Polish" collection Mit ash afn kop (1947), is dedicated to the victorious Red Army. Zak writes: "Let the iron tanks be praised / those that spit lead and embers, / throwing fire on the streets of Berlin, / overcoming every barricade." 43 Although this poem seems to be reminiscent of socialist realist panegyrics, I am inclined to see in it an expression of a survivor's genuine gratitude towards the Soviet soldiers for their contributions to the overthrow of fascism. In his memoirs Zak clearly stresses that the defeat of the Germans, and particularly the capture of Berlin, was a momentous event to him, as it brought about compensation (no matter how slight) for the harm the and humiliation, for the sense of one's own helplessness, in the face of the Holocaust:

Polish divisions - the newspapers report - are fighting near Dresden and Berlin. Here, many of us, Polish Jews, envy the Jewish soldiers who are so lucky to experience taking vengeance upon the murderers of our nation... Who can see with their own eyes, from close up, our greatest enemies - yesterday's representatives of the "Herren-Rasse" - being smashed and pulverized... Savouring such revenge, being so close must be most fortunate, and a great privilege. Being able to add more gunpowder to the fires [burning the German cities down]. ${ }^{44}$

As I have mentioned, Zak's poetic output of his refugee period is marked by circumspection, both in terms of accusations against, and praise for the Soviet "motherland of the proletariat." Meanwhile, in two poems written in the spring of 1945 the Red Army becomes an object of the poet's great admiration - exactly because the writer sees in it the long arm of justice inflicting legitimate punishment upon the murderers of his nation.

Another writer to portray the experiences of wartime wandering is Leyb Morgentoy. In his literary legacy we find poems reflecting the shock and panic that broke out on 22 June 1941, when Germany invaded the USSR. ${ }^{45}$ Together with other residents of the area that had been attacked by German troops at that time, the poet set out on a long and gruelling journey into the interior of the Soviet Empire, which eventually saved his life. One of the works offering an account of those hardships is the poem "Dushne teg" [Muggy days] from 1941: "Hard benches, harder still the days and nights. / Head to head, legs and arms intertwined. / The eyes have forgotten sleep, / and the dusty mouth burning with thirst." 46 The poem documents the hardships experienced by all refugees, but the lyrical speaker, similar to Zak and many other Yiddish writers, inscribes that

42 Zak, "Tshibiu," in: idem 1949: 40-41.

43 Zak, "Gebentsht zoln zayn," in: idem 1947: 65.

44 Zak 1958, vol. 2: 326.

45 Morgentoy, "Dushne teg," "22-ter yuni” [22 June], "Kh'hob nokh nekhtn gehat" [Only yesterday I had] in: idem 1949: 5-10.

46 Morgentoy, "Dushne teg," in: idem 1949: 10. 
experience into the context of the history of the Jewish Diaspora. According to Morgentoy, the refugees (Yid. and Pol. "bezhentsy"), by humming "a new elegiac song" 47 add another chapter to the biblical Book of Lamentations.

Jewish wanderers, similar to those of other nations fleeing the war, were plagued by lack of permanent accommodation and opportunities to earn a living, extreme poverty, hunger, and epidemics. Before representatives of the Polish Embassy in the USSR, and later also the Communist activists from the Union of Polish Patriots (Związek Patriotów Polskich, ZPP) took care of the refugees, they could only count on themselves. ${ }^{48}$ Many of them spent months on end travelling by train, searching the enormous stretches of the Soviet Empire for a place to live. In a poem titled "Balade fun mentsh mitn shisele zup" [The ballad of the man with a bowl of soup], written in Samarkand in 1942, Moyshe Knapheys explores one strategy for coping with traumatic homelessness; escaping into the world of poetic imagination. The protagonist of his narrative poem is a shabby, halfstarved man who stands on a street corner in a foreign, Asian town with a bowl of hot soup in his hands, imagining that he is at home. His imagination enables him to forget for a moment about the endless, awful journey in a crowded army train, about the fact that he must share his plank bed with louse-infested people whose bodies are covered with scabs, and that he himself has wounds on his legs and walks with a limp. However, as soon as the pleasure provided by the warm meal is finished, the dream of happiness vanishes, and the refugee does not know when he will be blessed with another moment of comfort and oblivion. ${ }^{49}$

For many writers immersing themselves in the beauty of the Orient was a form of escape from the hardship of everyday life. Despite the dramatic circumstances, the culture of Central Asia and its exotic nature made a great impression on the refugees who devoted many beautiful poems to it. ${ }^{50}$ During his sojourn in Almaty in 1942 Moyshe Knapheys enthuses not only over the local nature, but also over the people - their exotic customs, costumes, language, and beauty. He is thrilled by a visit to a local market one foggy day:

From the dense, dull fog a mountain emerges -

a towering, shaggy camel.

He stops - as if scanning the market for the exit, embarrassed by his own clumsiness.

Between his humps a steppe woman sits with confidence -

A Kazakh woman and a camel, grown together.

Behind them, laughing children - gaping awestruck,

craning their necks.

The camel with the yellow sacks collapses heavily, as if suddenly sinking down to his knees.

It seems that he's flown over here

from the other side of the hill.

\footnotetext{
47 Ibid.

48 Boćkowski 1999 and Głowacki 1994.

49 Knapheys, "Balade fun mentsh mitn shisele zup," in: idem 1948: 115.

50 Poets Avrom Zak, Moyshe Knapheys, Binem Heller, Leyb Morgentoy, Nakhmen Rapp et al. have shown great sensitivity to the exoticism and beauty of the Orient's culture and nature.
} 
The slender steppe woman nimbly dismounts it and grows before my eyes

- colourful and unreal against the grey mist -

as if cut out from a fairy tale. ${ }^{51}$

Interestingly, to those refugees who had received a cheder education in their childhood, attending a traditional religious school, the atmosphere of the Orient might have seemed reminiscent of the ancient Jewish state. Thus, for example, in the poem "Bukhare" [Bukhara] from 1942, Avrom Zak says: "Your strongholds remind me of the Jerusalem / I once saw in a cheder. / I think of the ancient East seeing your mosques / and narrow streets running uphill and down in the valley." ${ }^{2}$ Still, regardless of all the delights and positive sensations offered by the Orient, it appears from the literary texts published in post-war Poland and from the later memoirs that the refugees owed the most to the hospitality and friendship of the people they encountered. The presence of a kind person helped them to survive the tough moments, so it is no wonder that the motif of support provided by the USSR's residents often recurs in the literature written by the "survivors in the East," especially in the short stories. In a story titled "Unter vayte himlen" [Under the distant sky], prose writer Yosef Okrutny tells of a Polish Jew named Yekhiel who during the war finds himself in Kirghizia, where he is plucked from homelessness, destitution, and hunger by the family of an old Kirghiz Akhmejan:

Yekhiel was often plagued by hunger - by an unbearable, overwhelming hunger for bread. In a foreign country, in hard times, trying to soothe his aching entrails, he was roaming around the suburban fields, picking ears of corn and grinding the grains with his teeth; raw cabbage stalks and corncobs were also food for his stomach. [...] Yekhiel was, indeed, lucky. Babay Akhmejan took him in to his low, clay kibitka and shared his own meal with him. [...] They all slept together, under one roof, on the same bed of coarse felt, and the same pillows. ${ }^{53}$

When, after some time, Yekhiel recovers, he resolves to join the Red Army to fight against the Germans. Upon leaving Akhmejan's family, he is tormented by one question: "What should he say, straight from the heart, to these people who have done so much good to him? And there is so much he would like to tell them, to shout out, to cry, pouring his shaking heart out." 54

The theme of friendship and support offered by strangers also appears in Yitskhok Warszawski's short story "Dvoyres foter" [Dvoyra's father]. The protagonist is an old man whose daughter has gone missing in the course of the wartime migration of people. He spends a long time waiting for her at a railway station somewhere in the USSR, and eventually becomes seriously ill. In the hospital he is looked after by Dora, a young nurse who has also lost her father in the war. The old man and the girl nursing him become close friends, and then one day:

The patient slowly opened his eyes, looked at the world around him like a new-born baby, and it was only when he noticed the nurse dropping her eyes, her childish face blushing, he heaved a deep sigh. It was a sigh of great longing which resounded with such sadness throughout the

\footnotetext{
${ }^{51}$ Knapheys, “Alma-Ata in nepl" [Almaty in the fog], in: idem 1948: 125.

52 Zak, "Bukhare," in: idem 1947: 36.

53 Okrutny, "Unter vayte himlen,” in: Yidishe Shriftn 1948, no. 10: 6-7.

54 Ibid.: 7.
} 
hospital ward. [...] The nurse was confused for a moment, but she soon bent over the patient's bed and started to calm him down with childlike tenderness. He pressed her hot, plump hand to his heart and whined softly. "Rachel... Rachel... She was so young, just like you, and she had golden hair, too. Rachel... Rachel..." - he whispered.

The girl cast her eyes downward. She watched the man silently for a while, and then quietly, as if addressing his bed, she whispered: "But I'm so lonely too." And she burst into tears, full of woe. He stroked her little blonde head in a fatherly gesture, then pressed her warm hand more firmly.

- Do not despair, daughter mine, do not cry, my child...

After a few days, the entire sandy Uzbek neighbourhood was buzzing with the news that Dora the nurse had found her father. ${ }^{55}$

We may ponder over the propagandistic aspect of this kind of optimistic text written, in a sense, to please Communist censorship; ${ }^{56}$ still, I dare say that propaganda, although undoubtedly present in many works included in the group we are discussing here, coexists with accounts of real experiences shared by Yiddish refugee writers from Poland.

$$
* * *
$$

Literature published in post-war Poland, even if it had been cut to fit into the political determinants of its time, undoubtedly reflects a certain aspect of the wartime odyssey in the USSR. Fleeting emotions were aptly registered, especially in poetry, and for that reason the overall message it conveys, contrary to the hope-bearing prose, is far from optimistic. This is hardly surprising, because the news coming from Poland was tragic, not to mention incomplete. It remains unclear how scraps of information about the Holocaust reached individual people staying in the Soviet Union. At the beginning of the war, the news came with each wave of new refugees. Until the outbreak of the German-Soviet war, mail exchanged between Nazi-occupied Poland and even the most remote corners of the USSR was delivered as usual. ${ }^{57}$ From June 1941 onward, the source of the news for some refugees, such as Ukhtizhemlag inmate Avrom Zak, became the broadcasting stations at the forced labour camps which reported the Nazis' actions as Germany's

55 Warszawski, "Dvoyres foter," in: Yidishe Shriftn 1947, no. 7/8: 18.

56 On the adaptation of writers based in Białystok to the Soviet model of culture that drastically limited freedom of speech (e.g. on the subject of the fate of Jews in Nazi-occupied Poland) see Estraikh 2016: 184-186. As far as approaches to the Holocaust in post-war Poland are concerned, one example of the early ideologization of literature is the programme formulated by David Sfard, editor of the Yidishe Shriftn monthly and president of the Yidish Bukh publishing house. Sfard stressed the necessity of emphasizing the courage, optimism, and vital force of the characters appearing in the literature dedicated to the Holocaust, as well as the need to reject the formula of Biblical lamentations and replace it with writing in the spirit of optimism. See Sfard, “Mit zeyer toyt hobn zey undz bafoyln tsu lebn,' Yidishe Shriftn 1946, no. 4: 1-2. Another example of manipulating literature we could list here is the guideline for the organizers of a one-act play contest for drama clubs presented in Yidishe Shriftn 1948, no. 7/8. Back then, the following topics were considered desirable: life in democratic Poland; Jewish resistance movement during the war; the presence of Jews in the Red Army; national and social struggle in the interwar period; and life in Israel (at that time, still supported by the USRR).

57 E.g. Avrom Zak writes about the exchange of letters between Grodno (and even the Warsaw Ghetto) and Ukhta, and about the food parcels he received from his mother based in Belarus. See Zak 1956, vol. 2: $168-169,233,241,285-287$. 
invasion of the Soviet Union progressed. ${ }^{58}$ Later on, the news was transferred by the Soviet and Soviet-Yiddish press, such as the Yiddish Eynikeyt, ${ }^{59}$ as well as Communist papers in Polish, including Wolna Polska and Nowe Widnokregi, published in the war years (starting in 1943) by the Union of Polish Patriots (ZPP). ${ }^{60}$ People closely associated with the ZPP were, undoubtedly, among the best-informed, thanks to which Ber (Bernard) Mark, a ZPP collaborator and the future historian of the Warsaw Ghetto, was already in 1944 able to publish the first booklet, titled Powstanie $w$ ghetcie warszawskiem [The Uprising in the Warsaw Ghetto], ${ }^{61}$ in Moscow. It is from that booklet that the poet Moyshe Shklar (a factory worker in Magnitogorsk at the time) learned about the fall of the uprising. Shklar's reaction to the news was trauma, and it inspired him to compose "The Last," a dramatic narrative poem. ${ }^{62}$ Avrom Zak, on the other hand, found out the truth about the fate of his wife and son in the summer of 1944 from his wife's friend's sister who was living in the USSR and was kept informed about everything by a witness. This is how the poet described his reaction to the news that only about thirty thousand Jews had survived in Poland:

Sadness drives me out, into the snowy steppe, far from the city. Out there, I am absorbed by the white solitude. It seems to me I am walking among graves... Everywhere I set my foot graves!... So many graves! Steppe full of graves! - - - - - I have the impression that my feet get entangled in the mortal shrouds - - -

I cross the endless whiteness of the takhrikhim, ${ }^{63}$ the burial clothes without an end [...] And I feel I am being followed by shadows... Shadows of my friends. Shadows of my loved ones... ${ }^{64}$

Uncertainty about the fate of their loved ones deepened the personal suffering of the refugees. This is how Shloyme Berliński, staying in Tashkent in 1945, describes in his short story "Di Yelins" [The Yelins] the reaction of his protagonist Mordekhay Yelin to the uncertain news from Poland:

58 See Zak 1956, vol. 2: 281, 289-294, 305 ff.

59 See Kerler 2003: 221-249. Eynikeyt - newspaper published by the Jewish Antifascist Committee in the Soviet Union in 1942-1948. The paper was established to enable Soviet Jews to gain the support of Jews living in other countries and on other continents for the warfare of the USSR. On Eynikeyt's editorial board served the most prominent Yiddish writers of the Soviet Union: i.e. Dovid Bergelson, Shmuel Halkin, Leyb Kvitko, and Itsik Fefer. Fefer in particular spared no effort to encourage Jews living in Nazi-occupied territories to resist. For more see Greenbaum, Eynikeyt, in: YIVO Encyclopedia of Jews in Eastern Europe (Accessed: 6 August 2010).

${ }^{60}$ For more on this subject see Koźmińska-Frejlak 2012: 241-247.

${ }^{61}$ I am grateful to Joanna Nalewajko-Kulikov for sharing this information with me.

62 See: Shklar, A Short Stroll Through a Long Life. Reminiscences (typescript): "For days on end I carried around the images of the Warsaw Ghetto aflame and, in the end, I took to my pen and as I wrote, it seemed to me that I was dipping my pen in blood. In the course of several sleepless nights when I wasn't working the night-shift, I wrote a dramatic poem called 'The Last'." I am grateful to Mr Jerzy Szklark for making his Father's memoirs available to me.

63 Takhrikhim (Hebrew, Yiddish) - burial shroud used for clothing the deceased, made from new, white, cotton or linen cloth. See the entry "Later religious dress," in Encyclopaedia Britannica https://www.britannica.com/topic/religious-dress/Later-religious-dress\#ref538576 (Accessed: 27 January 2020).

64 Zak 1958, vol. 2: 325 . 
He had just received a message about his small town in Poland from which the Gestapo officers had taken all the Jewish residents to a spot near a railway embankment, and no one had returned. His parents were among those who had been taken.

It was the lack of knowledge about the particulars of their death that had moved him most deeply, opening up in him the space for the most horrifying imaginings.

He distinctly saw his father with his luxuriant brown beard, standing in the wind, in the middle of a field, with a spade in his hand, digging the hard ground. He is standing there, his eyes fixed on the grave which is growing deeper by the minute.

This grave should be reserved for him, Mordekhay. ${ }^{65}$

Just how important the subject of the Holocaust was to the "survivors in the East" can be deduced from the multitude of literary works they dedicated to it, borne from the almost devout need to accompany the murdered victims. We can recognize a certain inner imperative that urged the survivors to undergo a traumatizing contemplation of the imagined fate of their relatives and friends, to accompany them (if only in their thoughts) on their way to death, and to mentally share their experience of suffering. ${ }^{66}$ Moyshe Knapheys even grants it the status of a moral duty, addressing the survivors in a narrative poem titled "Blut far blut" [Blood for blood], written in Almaty in 1944-1945:

Let the flame be revived

In your bones,

[The flame] with which your nation,

With open, bright eyes

Went, awake

To its sacrificial death

In the blasé of the dawn -

On the hangman's tree, from the noose,

At the site of execution, by suffocation,

On the pyre and in the river -

Illuminated by a pillar of fire.

Let the memory of that

Never, never ever,

Until your last breath,

Never die,

Let that torture to the loss of their senses,

The torture of every Jew

Screaming in the flames

Stand before your eyes. ${ }^{67}$

${ }^{65}$ Berlinski, "Di Yelins," in: Yidishe shriftn. Literarish zamlbukh 1946: 35.

${ }^{66}$ This phenomenon was identified e.g. in 1945 by M. Knapheys in a poem titled "Kh'bin in kholem geven ba dayn shtarbn," included in: Knapheys 1948: 111, and in 1946 by Leo Finkelshteyn in an article "Iber di gasn fun Maynts un Varshe," published in the first volume of the literary almanac Yidishe shriftn. Literarish zamlbukh 1946: 28 in which he writes: "[...] although many thousands of kilometres away, we accompanied the sacred martyrs on their way to the lime kilns (kalkh oyvns), watching and following their every footstep. $[\ldots]$ We are still haunted by the question what expression on the faces of the martyrs we should recall in our imagination. What did their appearance express? How did they behave towards their enemy? Did they march to their death with fear and humility, or did they show pride and contempt? [...] We want to know how the Jews of the ghetto experienced the widespread terror."

${ }^{67}$ Knaphys, "Blut far blut," in: idem 1948: 143. 
The poem refers to one of the most important prayers of Judaism - Shma Yisroel which contains a confession of faith onto one God, and is also said by Jews on their deathbed. ${ }^{68}$ However, the sense of the prayer has been radically changed here by the poet: according to Knapheys, the Holocaust discloses the emptiness of heaven, proving the absence of God who did not accompany His children in their misery in the shape of a pillar of fire, like He did when He assisted Israelites on their way from Egypt to the Promised Land (Exod. 13: 21-22). What happened was something quite the opposite: the Holocaust has brought about a new epiphany: the revelation of many millions of Jews who have been sanctified by their tragic death. ${ }^{69}$ And while God once said to Israel: "Hear, O Israel: The Lord our God, the Lord is one. [...] And these words, which I command thee this day, shall be upon thy heart. [...] and thou shalt talk of them when thou sittest in thy house, and when thou walkest by the way, and when thou liest down, and when thou risest up. [...] They shall be for frontlets between thine eyes." (Deut. 6: 4-8) - the poet, like a priest, now appeals to all the survivors to forever remember the massacred victims, and to put their sacred names before their eyes, like the name of the one God in the past.

The persecution and mass murder of Jews aroused a sense of belonging and solidarity with the murdered nation in the hearts of many people who had earlier ostentatiously distanced themselves from the traditional yidishkeyt. ${ }^{70}$ This kind of transformation can be observed, for instance, in the works of Communist Binem Heller who, despite his harsh attacks on those of the traditional Jewish world in his pre-war poems, ${ }^{71}$ forcibly emphasizes his emotional bond with the entire Jewish nation, regardless of class affiliations or political views of its individual members in his wartime writings. An excerpt from the beautiful poem "Khorev" [Ruin] stands as one vivid illustration:

Everything has passed, everything is in ruins,

it has been adjudged to my blood to be a guardian of the memory

of all - beggars, singers, porters,

husbands with hurried gestures, -

noble, virtuous wives,

${ }^{68}$ Shma Yisroel (Hebrew, Yiddish) - the title, and at the same time the first two words of one of the most important Jewish prayers "Hear, o Israel: the Lord our God, the Lord is one!" (Deut. 6:4) which encapsulates the creed of the Jewish faith. It is the first prayer that a father teaches his child, and also the last words said on one's deathbed. See the entry "Shema," in Encyclopaedia Britannica https://www.britannica.com/topic/ Shema (Accessed: 27 January 2020).

${ }^{69}$ The dethronement of God and sanctification of the innocently murdered Jewish nation is a significant trope in Yiddish poetry in the discussed period. It appears in the writings of authors representing disparate world-views among whom we will find ghetto prisoners (Yeshaye Shpigel and Yitskhok Katsenelson), along with survivors in the USSR (Reyzl Zhikhlinsky and Leyb Olitski). For more see Ruta 2017: 94-97.

${ }^{70}$ The word yidishkeyt is derived from the word yidish [Jewish], and means an emotional attachment to the Jewish nation and the Jewish lifestyle. In a narrower sense, it means a life of religious observance, in accordance with the principles of Judaism. See the entry "Yiddishkeit," in Wikipedia. The Free Encyclopedia https://en.wikipedia.org/wiki/Yiddishkeit (Accessed: 27 January 2020). The Holocaust changed people's attitudes towards traditional Jewishness, as in the case of Julian Tuwim who, as a result of such transformation, wrote a narrative poem titled "My, Żydzi polscy" [We, Polish Jews] in 1944, or Julian Stryjkowski whose mind, stirred by the news about the fall of the Warsaw Ghetto Uprising, developed an idea for a novel about a traditional Jewish shtetl titled Glosy w ciemnościach [Voices in the dark], although, as a Communist, this particular writer was far from any national resentments at that time.

${ }^{71}$ Dawid Sfard, poet and literary critic also mentions it in his article Binem Heller, in: Sfard 1949: 71. 
all of them, all of them

are burning in synagogues, in barns.

Dying from hunger and fever,

driven, to lie down in their grave

and wait for the last torment,

layer after layer - so peacefully,

and wait, to be buried

in the middle of their life,

in the middle of their life. ${ }^{72}$

And even though the lyrical speaker of Heller's wartime poems invariably dissociates himself from the religious roots of the Jewish tradition, ${ }^{73}$ the same poet embraces indiscriminately all the Holocaust victims with his thoughts, as in the narrative poem "Af mayrev" [To the west], composed in Almaty in 1942: "And now I painfully long for the life / that was thither swept off the surface of the earth. - / My song turns into Kaddish, / my words - mingle with the mist." 74

Finding out about the scale of the Holocaust aroused anger, despair, and a thirst for revenge among the refugees. The news about the Jews' passivity in the ghettoes and in death camps must have been difficult to accept, and it urged the refugees to raise questions about the possibility of organizing an active defence. The call to resist and take to arms after many centuries of passivity thus became one of the major themes resurfacing throughout the wartime literature. The sense of powerlessness must have been especially unpalatable to those writers who sympathized with Communism, which promoted, among other things, an active and uncompromising attitude to life, and the readiness to fight for one's ideals. ${ }^{75}$ At any rate, it was not only the Communist Jewish writers who wanted to prove to the world that Polish Jews were capable of fighting and defending their own dignity like any other nation. At this point, it is worth introducing an important observation made by Harriet Murav, a scholar focusing on Jewish literature in the USSR, who points out the perspective from which Soviet Jews looked at the Holocaust. How much their perspective differed from that which is reflected in the literature produced by Polish Jews! Soviet Jews looked at the Holocaust through the eyes of victims and victors at the same time, identifying with those who were being murdered, but also with the vanquishers of their nation's murderers, ${ }^{76}$ while refugees from Poland perceived Germans' actions "only" though the eyes of victims. While we are on this subject, we should bear in mind that about 460-480 thousand Jews (mostly Soviet) served in the Red Army during the war, which added a very concrete meaning to the idea of "soldier-Jew."77 Additionally, Jewish intelligentsia in the Soviet Union put a great deal of effort into creating the figure of hero-Jew. According to historian Arkadi Zeltser: "The concerns of the [Soviet-]Yiddish intelligentsia about the reputation of the Jews during the war

${ }^{72}$ Heller, "Khorev," in: idem 1948: 184.

${ }^{73}$ See e.g. Heller, "Ikh, der letster" [Me, the last one] and "Af mayrev" [To the west], in: idem 1948: $125,126-127$.

${ }^{74}$ Heller, "Af mayrev," in: Ibid.: 127.

75 See Slezkine 2004.

${ }^{76}$ Murav 2011: 150-195.

${ }^{77}$ See Arad 2010: 4. 
were nowhere as strongly expressed as in Eynikeyt's articles about Jewish heroism." 78 All of these factors - Soviet Jews' service in the Red Army that ultimately defeated the Germans, as well as the strenuous propaganda activity aimed at convincing the public of the heroism of Jewish soldiers - certainly left a trace in the minds and hearts of the Polish bezhentsy (refugees). Being aware of this context helps us to better understand the yearning of Jewish writers from Poland to see the Jewish masses in their Nazi-occupied motherland take up the fight. This desire was expressed in their works, which frequently took on an almost aggressive tone. Hadasa Rubin writes in 1942:

For centuries, unpunished, driven by desire,

A horde of boors has visited itself upon our homes -

Blades of swords in our bellies, iron of knives in our breasts,

And their hands they immerse in our blood in the name of God.

$[\ldots]$

But of what importance are the dead in the face of disgrace,

What kind of death is it without a struggle, despised and humiliated?

Who will erase the disgrace that is falling on us,

When heads are rolling, but hands are silent? ${ }^{79}$

Binem Heller, on the other hand, in the year of the Warsaw Ghetto Uprising, declares in his narrative poem "Yerushe" [Legacy] that the only legacy he wants to leave behind is that of hatred ${ }^{80}$ Hatred and dreams of vengeance are also among the major leitmotifs of the wartime poetry of Zak, a poet whose sensitivity is so different from Heller's passionate rhetoric and revolutionary fervour. ${ }^{81}$ In a poem titled "Nekome" [Revenge], written several months after the suppression of the Warsaw Ghetto Uprising, the writer summons the survivors to take revenge: "Revenge for the ghetto, / for the yellow patch, / for the gallows and the jibing, / for the death of millions, / for the yoke, for the disgrace / of man and God ..." 82

$$
* * *
$$

What conclusions can we draw from the above, very cursory, survey of the key themes and motifs present in the writings of Yiddish authors from Poland? This literature, written in (and about) exile, is not only an account of what was happening to Jewish writers during their sojourn as refugees in the USSR, but also a testimony to their coping with the enormous psychological burden caused by the awareness (or the lack thereof) of the fate of Jews under Nazi German occupation. The political polarization of post-war Europe, whose consequence was the Cold War, led to the division of the continent into opposing spheres of influence. Those survivors who found themselves living under the Soviet boot

78 Zeltser 2014: 106.

79 Rubin, "Tsum yidishn zelner" [To a Jewish soldier], in: eadem 1957: 9-10.

${ }^{80}$ Heller, "Yerushe," in: idem 1948: 133.

81 The writer himself mentions it in his introduction to the volume Mit ash afn kop: "While the tones of joy were heard no more in the heart of the Jewish poet, another flame was born and kindled in his mind - the flame of vengeance. Vengeance upon those who had disgraced and destroyed our nation... This motif, too, has been addressed in the present volume." See Zak 1947: 4.

${ }^{82}$ Zak, "Nekome," in: Ibid.: 63. 
after WWII did not have the chance to peacefully abreact the trauma they had experienced, and to openly mourn their losses. The political split was followed by the division of literary production into censored literature and literature published beyond the sphere controlled by Communist censorship. It should be stressed here that what emerges from all the literary texts published in post-war Poland, even despite the cuts and omissions caused by (self)-censorship, is an image of a Jewish community affected by deep trauma, hurt and - so it seems - split into two groups: survivors in the East (vicarious witnesses), and survivors in Nazi-occupied Poland (direct victim witnesses) ${ }^{83}$ I believe we should extend and broaden that image, make it more nuanced by complementing the reflections on Holocaust literature (which has been underway for many years) with reflection on the accounts of the experience of exile, Soviet forced labour camps, and wandering in the USSR in the entire corpus of literary works and memoirs of the Polish-Yiddish writers.

Translated by Maria Piechaczek-Borkowska

\section{BIBLIOGRAPHY}

\section{Primary sources}

Berliński, S. (1946), Di Yelins, in: Yidishe shriftn. Literarish zamlbukh, Lodz: 35-38.

Dzhigan, S. (1974), Der koyekh fun yidishn humor, Tel Aviv.

Edison, I. (1953), Mayne fir yor in Soviet-Rusland, Pariz.

Grim, P. (Grosman M.) (1949), In farkisheftn land fun legendarn Dzhugashvili (Mayne zibn yor leben in Ratnfarband - 1939-1946), vols. 1-2, Pariz.

Guterman, G. (1948), Der opgrunt roysht, Varshe.

Guterman, Y. (1949), In a puster shtot, Lodz.

Heller, B. (1948), Durkh shotn un shayn, Varshe.

Ivan, W.H. (1950), Af heymisher erd, Varshe.

Knapheys, M. (1948), Megilas Yid, Varshe.

Man, M. (1945), Di shtilkayt mont, Lodz.

Morgentoy, L. (1949), Ruinen in zun, Lodz.

Okrutny, J. (1948), Unter vayte himlen, Yidishe shriftn, no. 10: 6-7.

Rubin, H. (1957), Trit in der nakht, Varshe.

Segal, K. (1960), Getraye libe, Varshe.

Segal, K. (1981), Vu shmeterlingn shvebn, Yerusholaim.

Segal, K. (2017), Opowiadania z zabitego Miasteczka, Kraków.

Shklar, M. (n.d.), A Short Stroll Through a Long Life. Reminiscences, trans. from Yiddish by Hershl Hartman (typescript; for the original version see: Forverts / The Yiddish Daily Forward 22.10.201322.01.2014).

Warszawski, Y. (1947), Dvoyres foter, Yidishe shriftn, no. 7/8: 17-18.

Zak, A. (1947), Mit ash afn kop, Varshe.

Zak, A. (1949), Yorn in vandern, Buenos Aires.

Zak, A. (1956), Knekht zenen mir geven, vols. 1-2, Buenos Aires.

Zak, A. (1958), Af shliakhn fun hefker, vols. 1-2, Buenos Aires.

${ }^{83}$ See Ruta 2017: 33-42. 


\section{Anthologies}

Ruta, M. (ed.) (2012), Nie nad rzekami Babilonu. Antologia poezji jidysz w powojennej Polsce / Nisht bay di taykhn fun Bovl. Anotolgye fun der yidisher poezye in nokhmilkhomedikn Poyln, Kraków: https://www.academia.edu/37389324/Magdalena_Ruta_ed._Nisht_bay_di_taykhn_fun_Bovl. Antologye_fun_der_yidisher_poezye_in_nokhmilkomedikn_Poyln.

Ruta, M. (ed.) (2018), Nowe życie? Antologia literatury jidysz w powojennej Łodzi, Łódź: https:// wydawnictwo.uni.lodz.pl/produkt/nowe-zycie/.

\section{Periodicals}

Dos Naye Lebn 1945-1950.

Yidishe shriftn 1946-1968.

Yidishe shriftn. Literarish zamlbukh 1946, 1948 Lodz.

\section{Secondary sources}

Arad, Y. (2010), In the Shadow of the Red Banner. Soviet Jews in the War against Nazi Germany, Jerusalem.

Boćkowski, D. (1999), Czas nadziei. Obywatele Rzeczypospolitej Polskiej w ZSRR i opieka nad nimi placówek polskich w latach 1940-1943, Warszawa.

Boćkowski, D. (2006), Losy żydowskich uchodźców z centralnej i zachodniej Polski (bieżeńców) przebywających na terenie obwodu białostockiego w latach 1939-1941, Studia Podlaskie 16: 85123.

Estraikh, G. (2016), The Missing Years. Yiddish Writers in Soviet Bialystok, 1939-1941, East European Jewish Affairs 42, no. 2: 176-191.

Głowacki, A. (1994), Ocalić i repatriować. Opieka nad ludnościa polska w głębi terytorium ZSRR (1943-1946), Łódź.

Jockusch, L., and T. Lewinsky (2010), Paradise Lost? Postwar Memory of Polish Jewish Survival in the Soviet Union, Holocaust and Genocide Studies 24, no. 3: 373-399.

Koźmińska-Frejlak, E. (2012), Prasa, in: S. Buryła, D. Krawczyńska, and J. Leociak (eds.), Literatura polska wobec Zagtady (1939-1968), Warszawa: 241-247.

Kerler, D.B. (2003), The Soviet Yiddish Press: Eynikeyt during the War, 1942-1945, in: R.M. Shapiro (ed.), Why didn't the Press Shout?: American and International Joumalism during the Holocaust, New York: 221-249.

Levin, D. (1995), The Lesser of Two Evils. Eastern European Jewry under Soviet Rule, 1939-1941, Philadelphia: 126-143.

Molisak, A. (2020), 1939-1941 - eine besondere Epoche in Lwów/Lwiw, in: K. Schoor, I. Voloshchuk, and B. Bigun (eds.), Blondzhende Stern. Jüdische Schriftstellerinnen und Schriftsteller aus der Ukraine als Grenzgänger zwischen den Kulturen in Ost und West, Göttingen: 250-270.

Murav, H. (2011), Music from a Speeding Train: Jewish Literature in Post-Revolutian Russia, Stanford, CA.

Nalewajko-Kulikov, J. (2007), "Syjonistyczna z lekkim zabarwieniem PPR-owskim.” Dos Naje Lebn (1945-1950) - gazeta Centralnego Komitetu Żydów w Polsce, in: A. Grabski (ed.), Żydzi a lewica. Zbiór studiów historycznych, Warszawa: 257-278.

Nalewajko-Kulikov, J. (2008), Kilka uwag o wydawnictwie "Idisz Buch," in: M. Ruta (ed.), Nusech Pojln. Studia z dziejów kultury jidysz w powojennej Polsce, Kraków-Budapeszt: 129-164.

Nalewajko-Kulikov, J. (2009), Obywatel Jidyszlandu. Rzecz o komunistach żydowskich w Polsce, Warszawa.

Ocalony na Wschodzie. Z Julianem Stryjkowskim rozmawia Piotr Szewc (1991), Montricher (Suisse).

Ruta, M. (2008), Tematy literatury jidysz w Polsce lat 1945-1949. Rekonesans badawczy, in: M. Ruta (ed.), Nusech Pojln. Studia z dziejów kultury jidysz w powojennej Polsce, Kraków-Budapeszt: 248-250. 
Ruta, M. (2017), Without Jews? Yiddish Literature in People's Republic of Poland on the Holocaust, Poland and Communism, Kraków.

Sfard, D. (1946), Mit zeyer toyt hobn zey undz bafoyln tsu lebn, Yidishe shriftn, no. 4: 1-2.

Sfard, D. (1949), Shrayber un bikher, Varshe.

Slezkine, Y. (2004), The Jewish Century, Princeton, NJ.

Szymaniak, K. (2006), Być agentem wiecznej idei. Przemiany pogladów estetycznych Debory Vogel, Kraków.

Wyrwa, T. (1992), Układ Sikorski-Majski, Zeszyty Historyczne, no. 102: 198-203.

Zeltser, A. (2014), How the Jewish Intelligentsia Created the Jewishness of the Jewish Hero. The Soviet Yiddish Press, in: H. Murav and G. Estraikh (eds.), Soviet Jews in World War II Fighting, Witnessing, Remembering, Boston: 104-128.

Żółkiewska, A. (2017), Zerwana przeszłość: Powojenne środowisko żydowskie inteligencji twórczej: Pomoc materialna i organizacyjna ze strony CKŻP, Warszawa.

\section{Dictionaries and encyclopedias}

Encyclopaedia Britannica, https://www.britannica.com/

YIVO Encyclopedia of Jews in Eastern Europe, http://www.yivoencyclopedia.org/

Wikipedia. The Free Encyclopedia, https://en.wikipedia.org/ 
